\title{
Evaluation of NTFPs in the Secondary Forest of Minko'o Village, in the South Cameroon
}

\author{
Tegno Nguekam Eric Wilson (Corresponding author), Ndjeudeng Tenku Simon \\ Centre de Recherche Spécialisé sur Forêt et Environnement, Meyomessala, Cameroun \\ Kaho Guimkia Gladys \\ Université de Dschang, Dschang, Cameroun
}

Received: Dec. 24, 2018 Accepted: Jan. 31, $2019 \quad$ Published: Feb. 20, 2019

doi:10.5296/jas.v7i1.14094 URL: https://doi.org/10.5296/jas.v7i1.14094

\begin{abstract}
Non-timber forest products (NTFPs) and some forest tree species are an important source of livelihood to communities. Unfortunately, their potential and uses are much unknown by the population or organization responsible for conservation. It is for this reason that this study was carried out in the village of Minko'o to assess this potential, and to show their importance. A socio-economic survey was carried out in the village and GPS coordinates of the identified NTFPs and forest trees was recorded from the farms/plantations and forest visited. A total of 20 households were surveyed in order to identify the different NTFPs and their utility for the population. Our findings revealed that $50 \%$ of the harvest of NTFPs and forest species is done by picking and $45 \%$ by collection. Some NTFPs and forest products were known and used by the people. Some of these resources were not known and therefore under exploited. It is the case of Cola (Cola nitida), Soursop (Persea muricata), Akom (Terminalia superba), Mfo (Enantia Chlorantha), Kassimang (Spondias purpurea). Most of NTFPs were grown by the populations and the preferred NTFP was the avocado tree. The forest tree species are mainly used for medicinal purposes. Other trees were used for construction.
\end{abstract}

Keywords: NTFPs, forest tree species, conservation, Forest

\section{Introduction}

Natural forests are home to human populations who have been living there for millennia, and are at relatively low level of socio-economic development. Forest are critical, in terms of day-to-day livelihoods, for millions of poor people, particularly in the developing world (Ashok et Pankal 2010). Human uses forest for many purposes, and the products derived from forest and their benefits, are referred to as "forest goods and services" (MEA 2005). 
Across the developing world, wild foods hunted or gathered from forests and other natural or modified ecosystems are vital for supplementing agricultural production by contributing to improved food availability and, more especially, food quality (Shackleton 2014).

Non-Timber Forest Products (NTFPs) are commonly understood as all the biological material (other than industrial round wood) available in natural ecosystems or managed plantation; such as fuel wood, fodder, food sources, medicinal plants and craft raw material (Ashok et Pankal 2010). NTFPs are considered important globally as they can contribute to proper nutrition as well as food security. In this respect, their potential to contribute to the climate change adaptation is well documented (Sonwa, Tiani, et Foahom 2013). They are vital in adding income to the families, thus improving rural livelihood. NTFP based enterprises that have high foreign demand can contribute to national income as well (Dhakal et al. 2016).

The current and future benefits of forest ecosystems are threatened by the inappropriate exploitation of their resources, caused by the lack of information on the potential they overflow (Massussi 2012). The forest species that provide a variety of non-timber products are often not recorded (Srivastava et Anitha 2010). One reason why NTFPs have not assumed a significant role in development interventions is largely due to lack of adequate quantitative data to highlight their significance in national and local livelihoods. Although it is amply evident that large numbers of people depend on them for livelihoods providing critical income and food during critical times of need (Issaka et Nartey 2016). The challenge for humankind is to continue to enjoy the benefits of using biodiversity resources without destroying them. It is therefore, crucial to protect and conserve them, in order to ensure their sustainable exploitation. This requires knowledge of the existing potential.

The objective of this study was to undertake a social and natural assessment of non-timber forest products in the Minko'o village, as a prerequisite for their sustainable management. Specifically, the study seeks:

- To identify the potential of NTFPs and forest tree species present in the Study area;

- To highlight the use and importance for the communities;

\section{Materials and Methods}

\subsection{Study Area}

Minko'o which is a village in Meyomessala is located in the South Region of Cameroon, in the Dja and Lobo division (Wikipedia 2018). The Council of Meyomessala is limited to North by the Council of Endom, North - West by the Council of Zoétélé, South by the Council of Meyomessi, South - East by the Council of Djoum, East by the Council of Bengbis and to the West by the Municipality of Sangmélima (CVUC 2014). This village is also located in the western periphery of the Dja Biosphere Reserve. Figure 1 shows the administrative and geographic location of Minko'o village. 


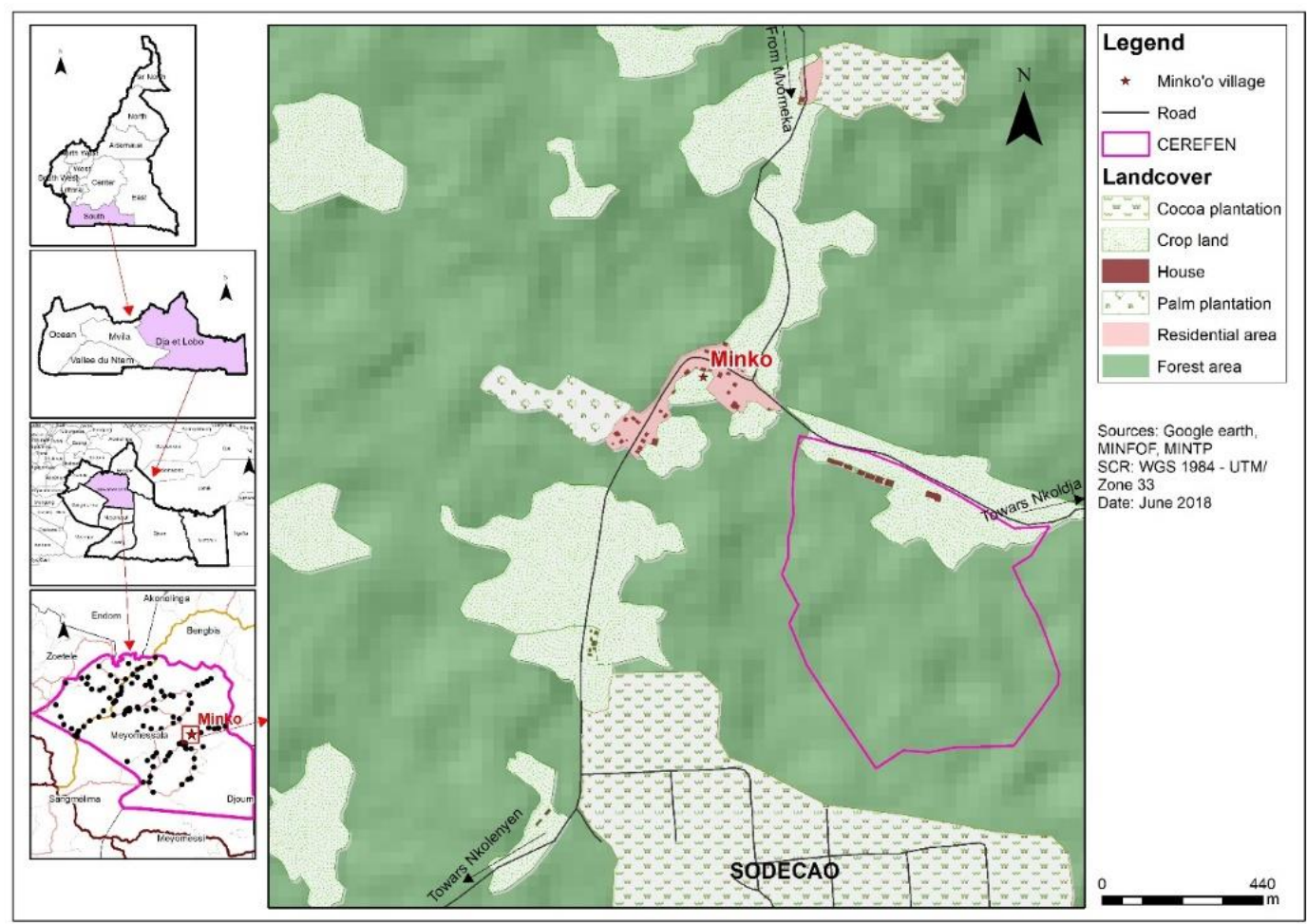

Figure 1. Geographic location of the study area

\subsection{Methodology}

\section{a) Preparation phase}

This phase was carried out according to the requirements of the Participatory Inventory of Non-timber Forest products methodology, of the Asia Network for Sustainable Agriculture and Bio resources (Ansab 2010). It was therefore, focused on a literature review; the establishment of contact with the community through the traditional authority; the design for data collection.

\section{b) Data collection phase}

NTFPs inventory approaches are often based on methods used in conventional forestry, that is sample plots and transect sampling strategies (Fongnzossie et al. 2013). A socio-economic survey was conducted using a questionnaire in the village of Minko'o. The aim was to gather information from different households about the different NTFPs and some forest tree species present in their village. This survey made it possible to draw up the socio-economic profile of the village and to know the contribution of NTFPs and forest tree species in the life of the populations and in the development of the village. Twenty households were surveyed out of thirty tree in the village.

Later on and following a participatory approach (Simionato and Hanazaki 2016), a visit of the farms / plantations of the people surveyed was carried out. The objective of this visit was to record using a GPS, the geographic coordinates of NTFPs and forest tree species that were mentioned during the survey. Positions of NTFPs and trees species were individually recorded as waypoints using a Garmin GPSMAP 60CSx GPS receiver. The GPS receiver is 


\section{Macrothink}

small, handy, and easy to use; these features are suitable for forest inventory (Tsuyuki et al. 2006). This GPS is equipped with a high-sensitivity SiRFstar III GPS chipset, which allows for relatively good GPS signal reception in a forested area (Owari et al. 2011). These coordinates helped to produce the map of NTFPs and forest tree species present in the village.

\section{c) Data analysis phase}

The survey data was entered into an Excel spreadsheet for analysis and graph production, while the geographic coordinates were analysed using Geographic Information System (GIS) software (Arcmap 10.5) for geo-referencing and map production.

\section{Results and Discussion}

\subsection{The Socio-economic Profile of the Village}

Minko'o is a relatively young village. The survey showed that $40 \%$ of the population is between the ages of 18 and 30 years (Figure 2). At the professional level, the survey shows that $80 \%$ of the population practices agriculture (Figure 3 ). Hunting $(5 \%)$ is very low in the village. This agriculture is oriented towards subsistence with plantain, cassava, cocoyams, yam, maize, peanut as the main crops cultivated.

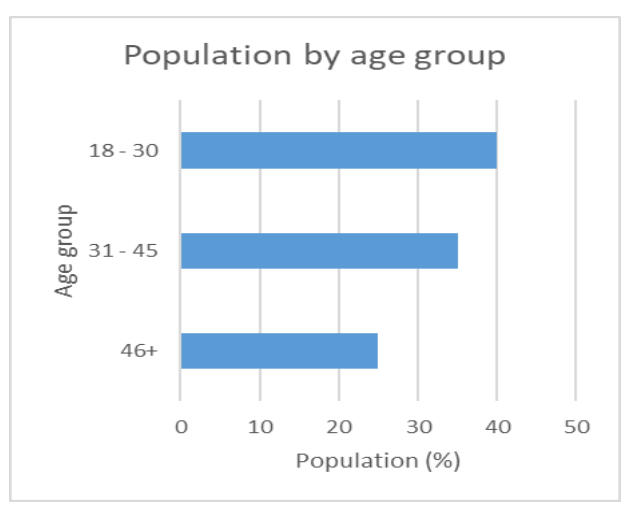

Figure 2. Population by age group

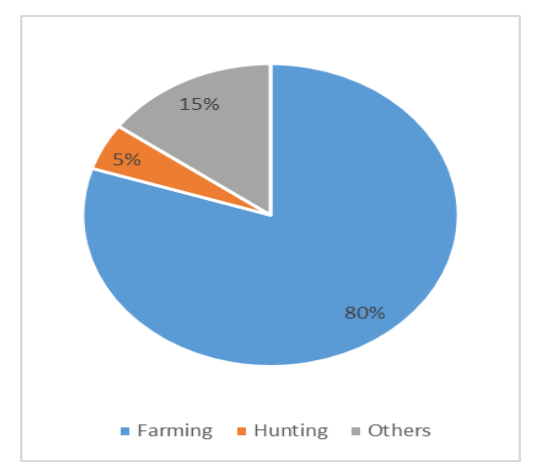

Figure 3. Economic activities of the village 


\section{Macrothink}

3.2 Non-timber forest Products and Forest Tree Species Identified in the Village

a) NonTimber Forest Products

The gathering of NTFPs in the village is done in several ways: collection, harvest and other methods (Figure 4).

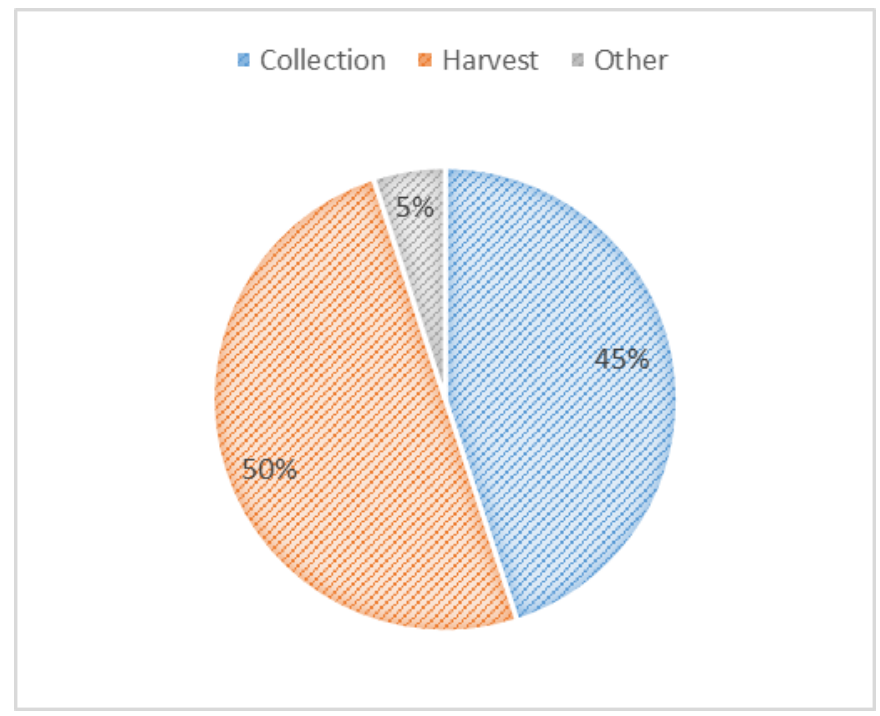

Figure 4. Methods of gathering NTFPs (2018)

As mentioned above, the main activity in the village is agriculture. In addition to the usual plantain, cassava, cocoyams, yam, maize and peanut, the survey showed that the people grown NTFPs, while other NTFPs are gathered from the forest.

About the collection, generally, the major raining season in Cameroon is considered as the main fruiting period of most species that produce NTFPs, such as wild mango, soursop (Lescuyer 2010). Figure 5 shows the frequency of collection in the village. On the basis of the declarations in the surveyed households, the major raining season between August and October represents the period of high collection activity.

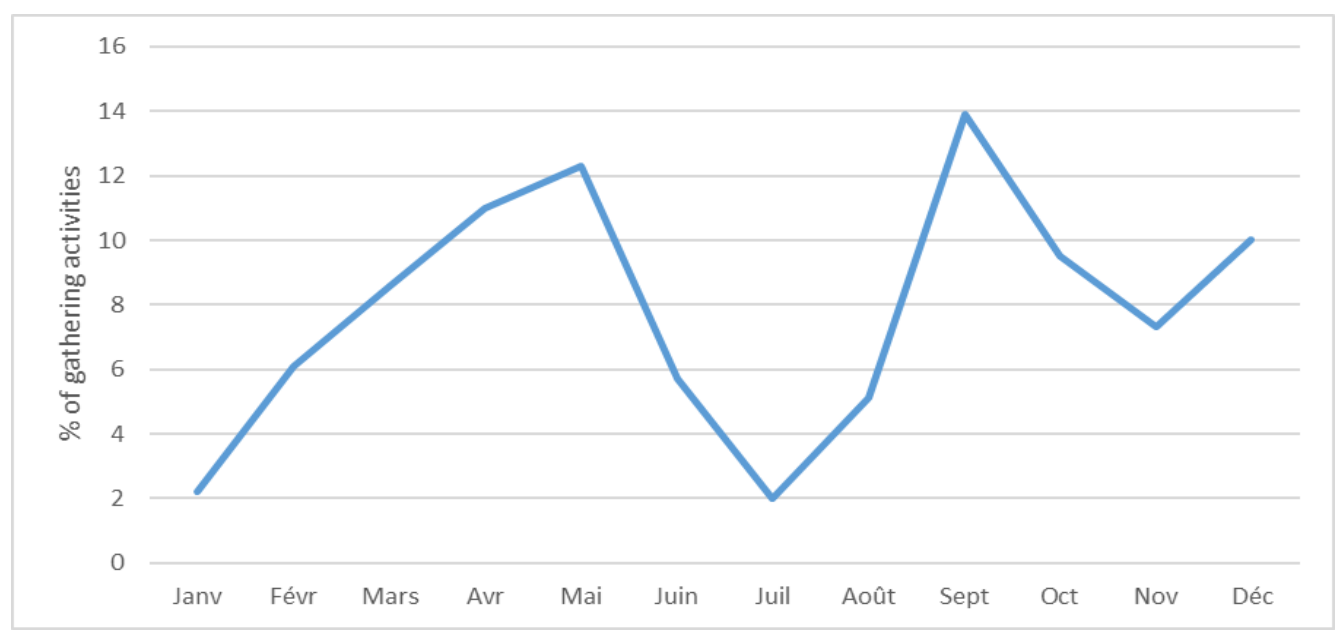

Figure 5. Frequency of gathering activities 
The principal NTFPs found and their uses are presented in the Table 1. The NTFPs collected are mainly intended for consumption with a preference of avocado tree and plum tree as shown in Figure 6 and 7 respectively. The Figure 8 shows the different NTFPs based on land use type while the Figure 9 shows the geographic location of identified NTFPs.

Table I. Identified NTFPs in the Minko'o Village

\begin{tabular}{|c|c|c|c|c|}
\hline Common name & Scientific name & $\begin{array}{c}\text { Number of } \\
\text { trees }\end{array}$ & Season of gathering & Uses \\
\hline Avocado tree & Persea amerricana & 13 & All the Year round & $\begin{array}{l}\text { The core of the fruit } \\
\text { was used to treat } \\
\text { stomach pain and } \\
\text { diarrhea }\end{array}$ \\
\hline Mango tree & Mangifera indica & 8 & From March to June & $\begin{array}{l}\text { The leaves } \\
\text { astringent and } \\
\text { odontalgic. } \\
\text { infusion of these } \\
\text { leaves is drunk to } \\
\text { reduce blood } \\
\text { pressure and as a } \\
\text { treatment for } \\
\text { conditions such as } \\
\text { angina, asthma, } \\
\text { coughs and diabetes }\end{array}$ \\
\hline Soursop & Persea muricata & 1 & & $\begin{array}{l}\text { Consumption. This } \\
\text { tree also has } \\
\text { medicinal properties }\end{array}$ \\
\hline Plum tree & Dacryodes edulis & 12 & $\begin{array}{l}\text { From June to } \\
\text { November }\end{array}$ & $\begin{array}{l}\text { The leaves were } \\
\text { eaten raw with cola } \\
\text { nut as an antiemetic }\end{array}$ \\
\hline Orange tree & Citrus sinensis & 4 & All the Year round & Consumption \\
\hline Lemon & Citrus limon & 3 & All the Year round & $\begin{array}{l}\text { The barks were used } \\
\text { for the treatment of } \\
\text { fever, running } \\
\text { stomach. The leaves } \\
\text { are boiled for the } \\
\text { manufacture } \\
\text { herbal tea }\end{array}$ \\
\hline Cola & Cola nitida & 1 & All the Year round & $\begin{array}{l}\text { Used for his } \\
\text { stimulating } \\
\text { properties. The cola } \\
\text { nut is composed of } \\
\text { caffeine, who is a } \\
\text { powerful intellectual } \\
\text { stimulant. }\end{array}$ \\
\hline Kassimang & Spondias purpurea & 2 & $\begin{array}{l}\text { From May to } \\
\text { November }\end{array}$ & $\begin{array}{l}\text { The leaf juice was } \\
\text { taken orally in the } \\
\text { treatment of swollen } \\
\text { glands and trauma. } \\
\text { The crushed leaves } \\
\text { were applied as a } \\
\text { poultice to treat } \\
\text { headaches }\end{array}$ \\
\hline $\begin{array}{l}\text { Ndo'o } \\
\text { mango) }\end{array}$ & Irvingia spp. & 1 & From June to October & $\begin{array}{l}\text { Fruits are used to } \\
\text { make wine, and it is } \\
\text { a good source of fat, } \\
\text { carbohydrates } \\
\text { and fiber. The kernel } \\
\text { or seed is the part } \\
\text { that is utilized the } \\
\text { most for medicinal } \\
\text { purposes }\end{array}$ \\
\hline
\end{tabular}




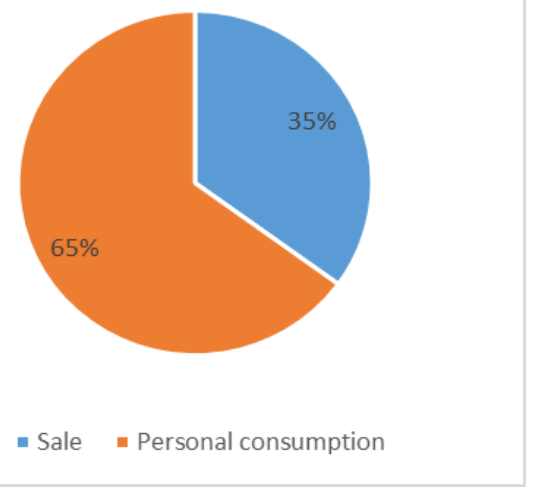

Figure 6. Destination of NTFPs

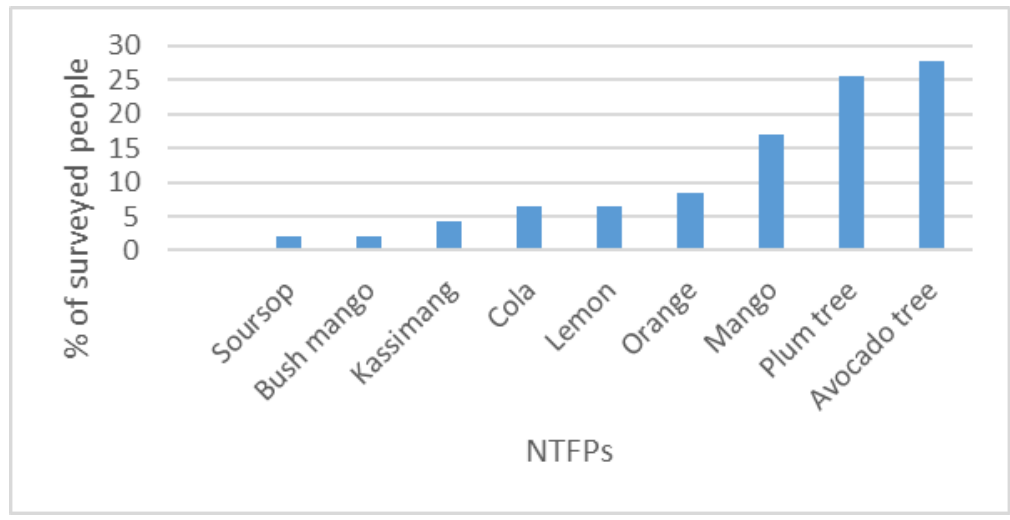

Figure 7. Preferences of NTFPs

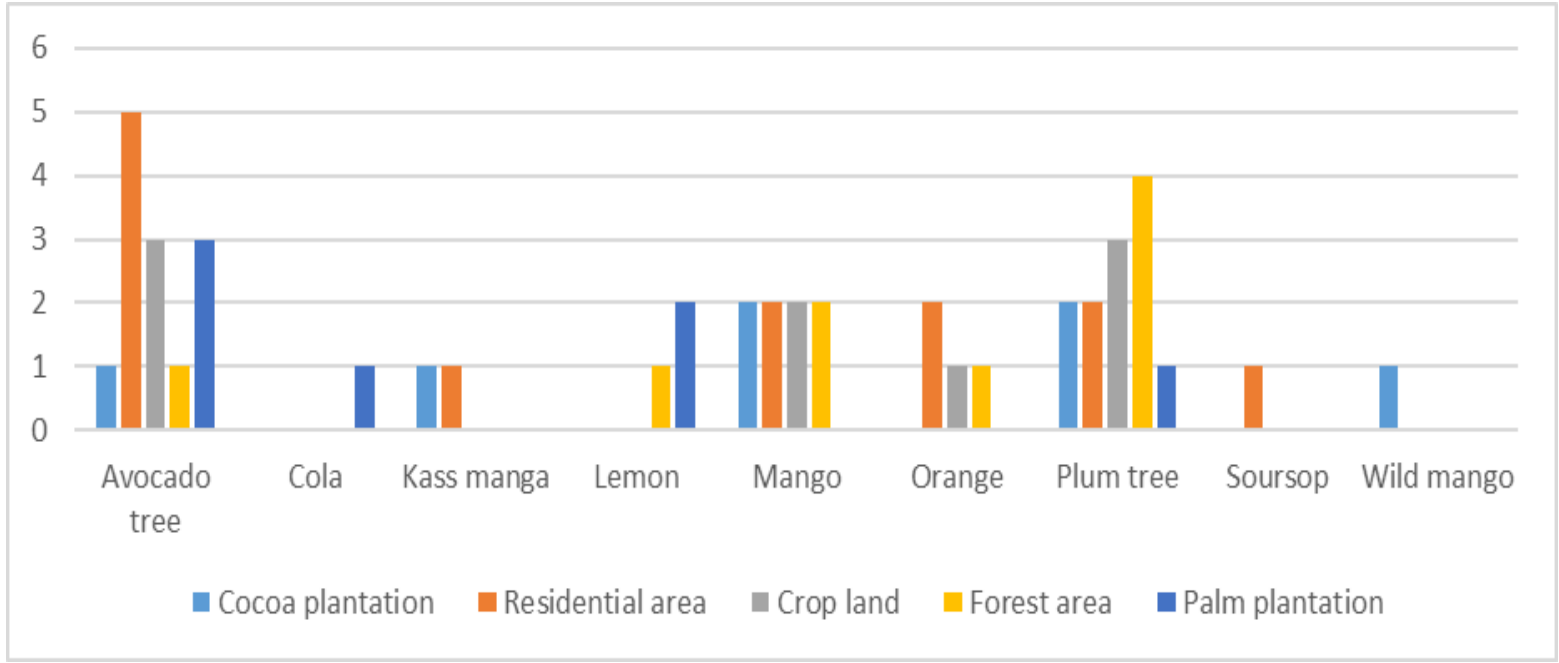

Figure 8. Identified NTFPs based on Land use type 


\section{Macrothink}

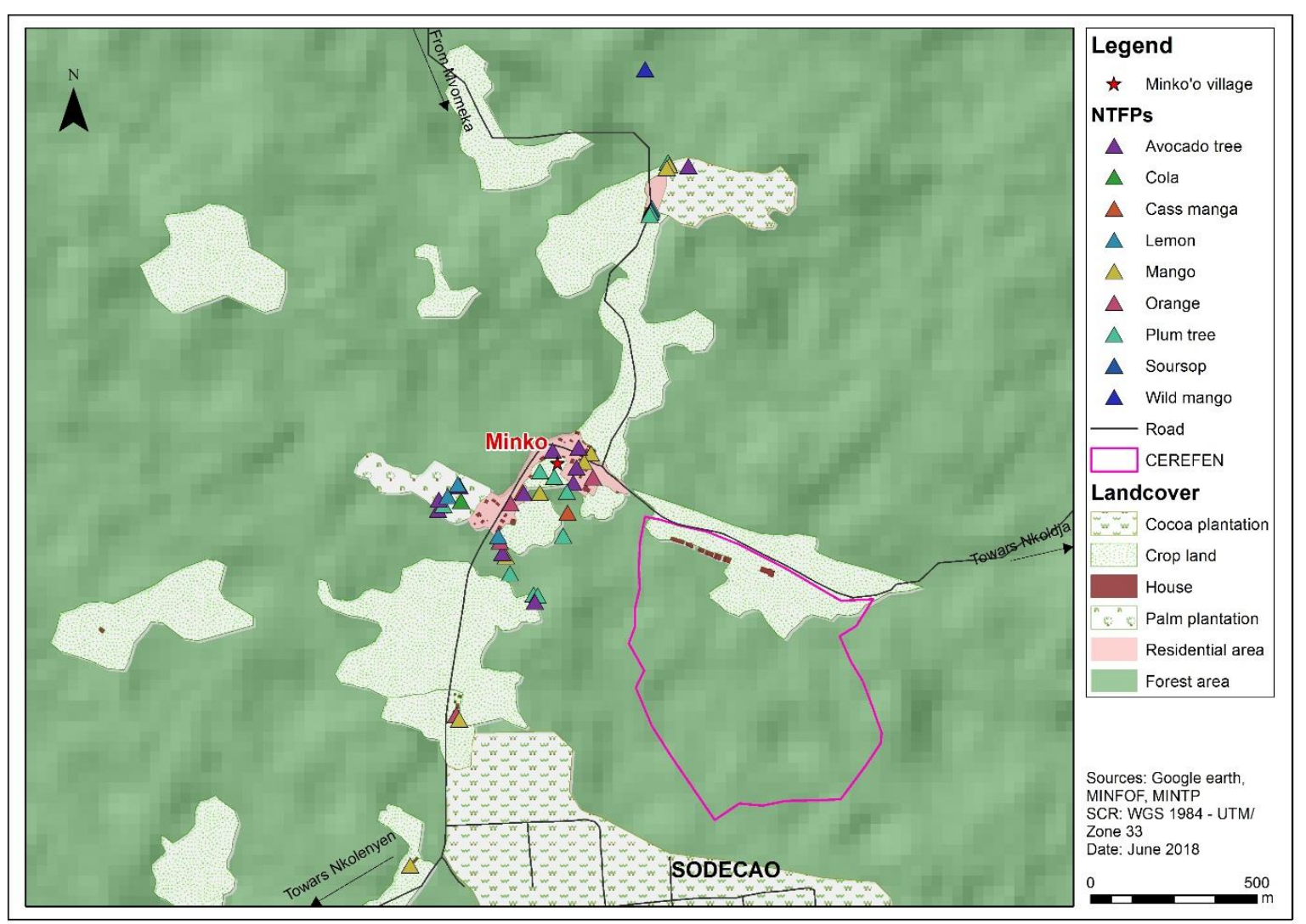

Figure 9. Geographic location of NTFPs

b) Forest Tree Species

To the population of Minko'o, forest plays an important role in the development of their village. Trees present in their forest are vital. They give out oxygen, store carbon, stabilize the soil and give life to the wildlife. Also they serve as windbreak, provide materials for tools and shelter. The Table 2 shows the list of identified forest tree species and their uses. The Figure 10 shows the geographic location of these trees. 


\section{Macrothink}

Table 2. List and uses of identified forest tree species

\begin{tabular}{|c|c|c|c|}
\hline $\begin{array}{l}\text { Vernacular } \\
\text { name }\end{array}$ & $\begin{array}{l}\text { Common } \\
\text { name }\end{array}$ & Scientific name & Uses \\
\hline \multirow[t]{2}{*}{ Adjap } & \multirow[t]{2}{*}{ Moabi } & \multirow{2}{*}{$\begin{array}{l}\text { Baillonella } \\
\text { toxisperma }\end{array}$} & $\begin{array}{l}\text { Its bark was used by people suffering from back pain } \\
\text { and women after childbirth }\end{array}$ \\
\hline & & & Its seed was used to make moabi oil \\
\hline Akom & Frake & $\begin{array}{l}\text { Terminalia } \\
\text { superba }\end{array}$ & $\begin{array}{l}\text { The bark is anodyne, astringent and expectorant. } \\
\text { Decoctions and macerations were used in traditional } \\
\text { medicine to treat wounds, sores, hemorrhoids, } \\
\text { diarrhea, dysentery, malaria, vomiting, }\end{array}$ \\
\hline Samba & Ayous & $\begin{array}{l}\text { Triplochiton } \\
\text { scleroxylan }\end{array}$ & $\begin{array}{l}\text { The plant was used in traditional medicine to treat } \\
\text { edemas and as an anodyne }\end{array}$ \\
\hline \multirow{2}{*}{ Mubala } & \multirow{2}{*}{ Ebaye } & \multirow{2}{*}{$\begin{array}{l}\text { Pentaclethra } \\
\text { macrophylla }\end{array}$} & Bark were used to drive snakes from the house \\
\hline & & & Leaf and stem decoctions were taken against diarrhea \\
\hline Baoba & Baoba & $\begin{array}{l}\text { Adansonia } \\
\text { digitate }\end{array}$ & Sacred tree used for some traditional ceremony \\
\hline Atui & Dabema & $\begin{array}{l}\text { Piptadeniastrum } \\
\text { africanum }\end{array}$ & $\begin{array}{l}\text { The bark of Dabema was commonly used in } \\
\text { traditional medicine, sometimes also roots and leaves. } \\
\text { Bark decoctions were administered internally against } \\
\text { cough, bronchitis, headache, mental disorders, } \\
\text { hemorrhoids, urogenital infections, gastric pains and } \\
\text { male impotence. As an antidote, externally, they were } \\
\text { used to treat fever, toothache, pneumonia, edema, skin } \\
\text { diseases and rheumatism, to expel worms, to chase } \\
\text { fleas, Decoction of bark also enters a leprosy } \\
\text { treatment complex. }\end{array}$ \\
\hline Mbele & Mbele & $\begin{array}{l}\text { Kantou } \\
\text { guereansis }\end{array}$ & Leaves used to treat ringworms \\
\hline Ekouk & Emien & $\begin{array}{l}\text { Alstonia } \\
\text { chlorantha }\end{array}$ & $\begin{array}{l}\text { The latex was purgative to treat abdominal pain. Use } \\
\text { the barks for malaria symptoms, aches, wounds, boils, } \\
\text { vomiting, yellow bitter, ever, chills, sore, spleen in } \\
\text { children and hepatitis. Used the barks for malaria } \\
\text { symptoms, aches, wounds, boils, vomiting, yellow } \\
\text { bitter, fever, chills, sore, spleen in children and } \\
\text { hepatitis. } \\
\text { Used the barks for malaria symptoms, aches, wounds, } \\
\text { boils, vomiting, yellow bitter, ever, chills, sore, spleen } \\
\text { in children and hepatitis }\end{array}$ \\
\hline
\end{tabular}




\begin{tabular}{|c|c|c|c|}
\hline Mfo & $\begin{array}{l}\text { Yello } \\
\text { moambe }\end{array}$ & $\begin{array}{l}\text { Enantia } \\
\text { chlorantha }\end{array}$ & $\begin{array}{l}\text { Used the barks for malaria symptoms, aches, wounds, } \\
\text { boils, vomiting, yellow bitter, ever, chills, sore, spleen } \\
\text { in children and hepatitis. Used the barks for malaria } \\
\text { symptoms, aches, wounds, boils, vomiting, yellow } \\
\text { bitter, fever, chills, sore, spleen in children and } \\
\text { hepatitis }\end{array}$ \\
\hline \multirow[t]{2}{*}{ Alondok } & \multirow[t]{2}{*}{ Bilinga } & \multirow{2}{*}{$\begin{array}{l}\text { Nauclea } \\
\text { diderrichi }\end{array}$} & $\begin{array}{l}\text { Used the barks for malaria symptoms, aches, wounds, } \\
\text { boils, vomiting, yellow bitter, ever, chills, sore, spleen } \\
\text { in children and hepatitis }\end{array}$ \\
\hline & & & $\begin{array}{l}\text { The bark was used in an infusion to treat gonorrhea, } \\
\text { and as part of an infusion for treating jaundice }\end{array}$ \\
\hline \multirow[t]{2}{*}{ Eyen } & \multirow[t]{2}{*}{ Movingui } & \multirow[t]{2}{*}{$\begin{array}{l}\text { Distemonanthus } \\
\text { benthamianus }\end{array}$} & $\begin{array}{l}\text { The leaves, pulped with palm-oil, were used } \\
\text { externally as a massage to maturate furuncles and to } \\
\text { relieve migraine and rheumatism. They were also } \\
\text { used to massage children who are late in learning to } \\
\text { walk; }\end{array}$ \\
\hline & & & $\begin{array}{l}\text { A tisane made from the roots is given as a treatment } \\
\text { for rhino-pharyngeal and pulmonary affection }\end{array}$ \\
\hline Assam & Rikio & $\begin{array}{l}\text { Uapaca } \\
\text { guineensis }\end{array}$ & Fruits were being used for food \\
\hline \multirow[t]{2}{*}{ Bibolo } & \multirow[t]{2}{*}{ Bibolo } & \multirow{2}{*}{$\begin{array}{l}\text { Lavoa } \\
\text { trichilioides }\end{array}$} & $\begin{array}{l}\text { The pulped bark is rubbed on the chest to treat } \\
\text { pulmonary trouble }\end{array}$ \\
\hline & & & The bark was also used against dental caries \\
\hline \multirow{3}{*}{ Obang } & \multirow{3}{*}{ Obang } & \multirow{3}{*}{$\begin{array}{l}\text { Schrebera } \\
\text { arborea }\end{array}$} & $\begin{array}{l}\text { The fresh twigs were an ingredient of a preparation } \\
\text { that is taken to treat skin disease }\end{array}$ \\
\hline & & & $\begin{array}{l}\text { The seeds were applied to the heads of children to } \\
\text { treat skin complaints }\end{array}$ \\
\hline & & & $\begin{array}{l}\text { Macerations of the twigs were administered as a } \\
\text { purgative to treat abdominal pain }\end{array}$ \\
\hline Fep & & & Protection \\
\hline \multirow{6}{*}{ Njangsa } & \multirow{6}{*}{ Njangsa } & \multirow{6}{*}{$\begin{array}{l}\text { Ricinodendron } \\
\text { heudelotii }\end{array}$} & The kernels were eaten boiled in water or in \\
\hline & & & sauce, or mixed with fish, meat and other \\
\hline & & & vegetables \\
\hline & & & A decoction of the bark was used in the \\
\hline & & & treatment of cough, painful menstruation \\
\hline & & & and as an antidote to poison \\
\hline Inga & & & Fruit used as condiment \\
\hline
\end{tabular}




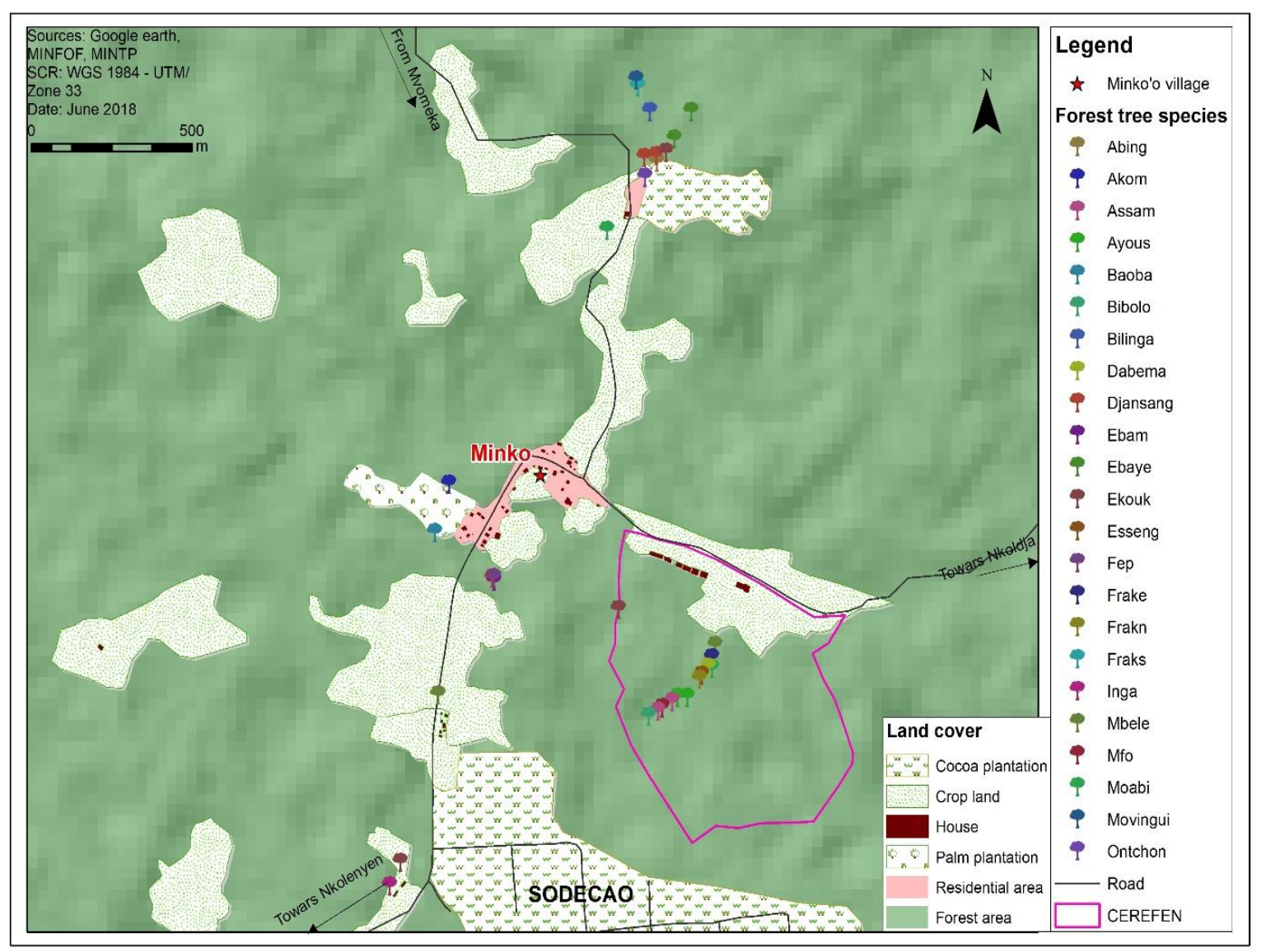

Figure 10. Geographic localization of forest tree species

Most of the forest tree species identified during the inventory were located in forest and farms. There is a greater concentration of forest tree coming from Mvomeka a nearby village, less in the village itself and a few going towards SODECAO.

The population of Minko'o surveyed believe that these forest products play a key role in the development of the village as they can contribute in the fight against climate change. NTFPs can be sold for incomes, while some forest tree can be used in the construction of the village. Figure 11 shows the opinions of surveyed people on the key role of forest products.

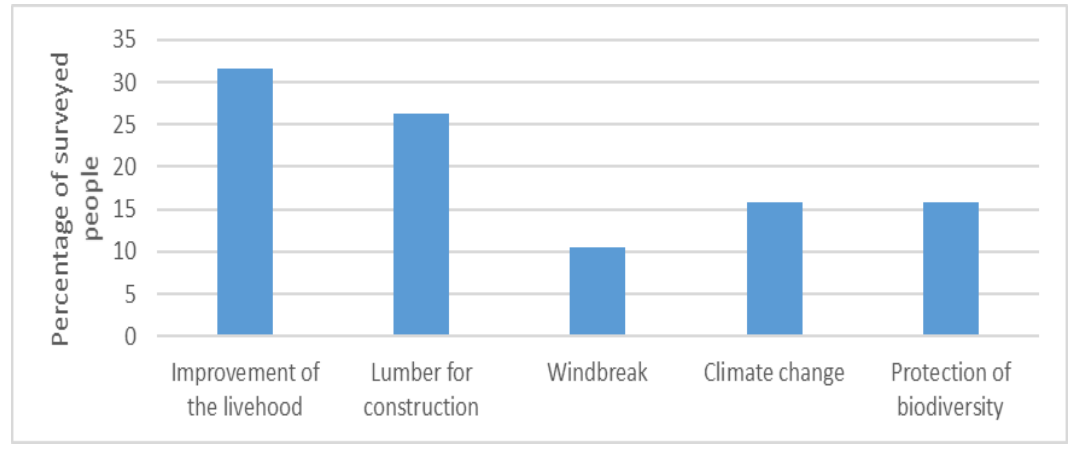

Figure 11. Key role of NTFPs and forest tree in the development of Minko'o 


\section{Ml Macrothink}

The Analysis of data collected during the surveys showed that there is a not very strong correlation between the consumption of NTFPs and their availability in the village $(C=0.68)$. Indeed, the number of times the NTFPs have been mentioned is higher than the inventories done in the field. Figure 12 shows the point cloud and the linear correlation between these two parameters. This survey showed that some forest products are not well-known as they were less mentioned by the people during interviews. It is the case of Cola (Cola nitida), Soursop (Persea muricata), Akom (Terminalia superba), Mfo (Enantia Chlorantha), Kassimang (Spondias purpurea).

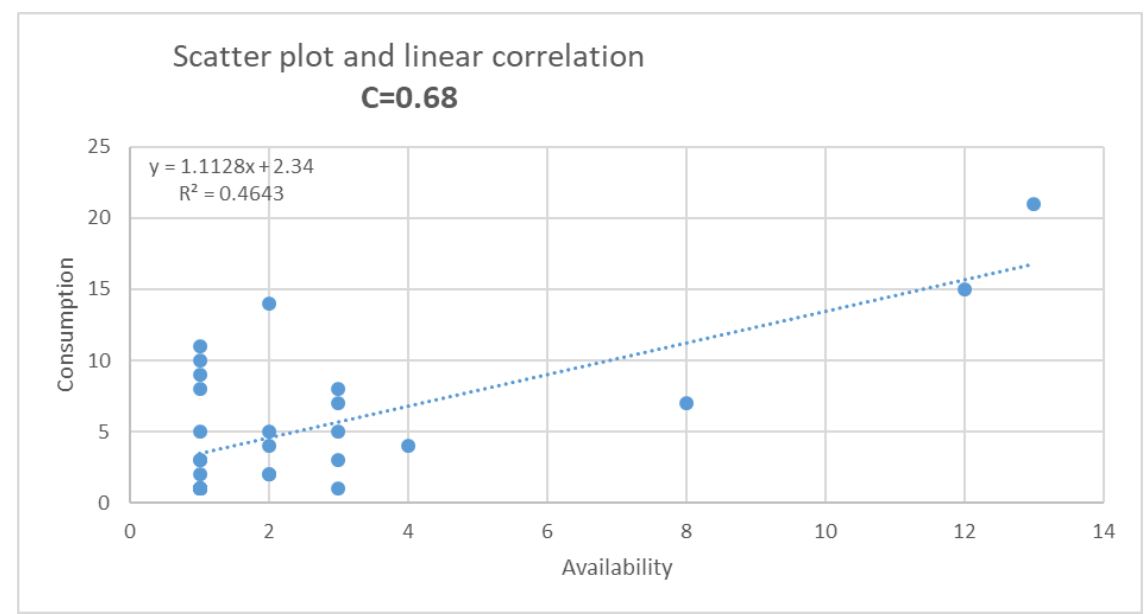

Figure 12. Correlation between consumption and availability of NTFPs

The development of NTFPs is considered as one of the tools for tropical forest management (Tchatat, Ndoye, and Nasi 1999). Similarly, it can also be used in the conservation of plant species through domestication (Tonga Ketchatang et al. 2017). Concerning conservation, the population of Minko'o thinks that NTFPs species preserved by them need to be protected in managed forest. It is the case for Irvingia gabonensis, Baillonella toxisperma. During the harvesting of cocoa pods, some species of NTFP are preserved by the populations. These useful trees left and often characteristic of the original forest are abundant and naturally grow. They have the advantage of being located closer to homes.

\section{Conclusion and Recommendations}

The study conducted in the village of Minko'o has shown that there is a wealth of non-timber resources and forest trees distributed throughout the village. These resources enable the nutrition of the village populations by serving as a supplement to the agricultural products usually grown. Some forest products are used in traditional medicine as seen the case of Ekouk (Alstonia chlorantha) which is used in the treatment of stomach ache. This study also revealed that for the populations, these forest and non-timber resources play an important role in the life and development of the village. The protection and domestication of these resources is an effective way to fight against food insecurity and climate change adaptation. They are also a source of financial income when marketed.

In terms of recommendation, a study on the inventory of NTFPs and their uses in the 
peripheral zone of the Dja Biosphere Reserve should be conducted so that communities will be aware of the potential of their environment. This awareness will allow the valorization and the sustainable management of these resources. Some NTFPs as Ndo'o (Irvingia spp.) could be domesticated. This will require the strengthening of communities' capacities on cultivation techniques and sustainable harvesting of these products, with possible impacts on their standard of living.

\section{References}

Ansab, ed. (2010). Participatory Inventory of Non-Timber Forest Products. First edition. Rural Development Toolkit Series, toolkit 2. Kathmandu: Asia Network for Sustainable Agriculture and Bioresources.

Ashok, K. P., \& Bhargava, P. (2010). Impact of Climate Change on Non Timber Forest Products: An Overview. Journal of Tropical Forestry, 26(IV) (December), 9.

Cvuc. (2014). MEYOMESSALA.

http://cvuc.cm/national/index.php/fr/carte-communale/region-du-sud/90-association/carte-ad ministrative/314-meyomessala

Dhakal, P., Dev, R. P., \& Dilli, R. B. (2016). Inventory of Non-Timber Forest Products in Western Nepal and Strategies for Sustainable Management. International Journal of Environment, 5(3), 87. https://doi.org/10.3126/ije.v5i3.15707

Fongnzossie, E., Marlène, N., Louis, Z., Aimé, V. K., Denis, J. S., Merlin, G. N., \& Bernad-Aloys, N. (2013). Density and Natural Regeneration Potential of Selected Commercial Non Timber Forest Products in the Mixed-Evergreen Rainforest of South Eastern Cameroun. Progress Report 2013, 2013.

Issaka, B. Y., \& Richard, Y. N. (2016). Non-Timber Forest Products and Climate Change Resilience: The Case of the Savannah Woodlands Northern Ghana, 8.

Massussi, J. A. (2012). Presentation Du Centre Specialise De Recherche Sur Foret Et Environnement (Cerefen). Irad/Cerefen.

MEA. (2005). Our Human Planet: Summary for Decision Makers, 2005.

Owari, T., Noriyuki, K., Motokazu, S., Ryuji, T., Yuji, N., \& Masaki, T. (2011). Using Global Positioning System (GPS) Technology for Tree Marking in a Natural Forest under a Single-Tree Selection System. FORMATH 10 (March), 105-121. https://doi.org/10.15684/formath.10.105

PNDP. (2014). Plan Communal de Développement de Meyomessala.

Shackleton, S. (2014). Impacts of Climate Change on Food Availability: Non-Timber Forest Products. In Global Environmental Change, 695-700. Springer, Dordrecht. https://doi.org/10.1007/978-94-007-5784-4_117

Simionato, M. M., \& Natalia, H. (2016). Characterization And Participative Mapping Of Non-Timber Forest Product Extraction: The Case Of Leatherleaf Fern Rumohra 
Adiantiformis (G. FORST.) CHING. Ethnoscientia, 1(1).

https://doi.org/10.22276/ethnoscientia.v1i1.21

Sonwa, D. J., Anne, M. T., \& Bernard, F. (2013). Forêts et Adaptation Aux Changements Climatiques Au Cameroun: Réalités, Défis et Perspectives à Partir Des Études Dans Le Cadre de COFCCA-COBAM. In . Yaoundé 23 au 25 Juillet 2013.

Srivastava, V. K., \& Anitha, D. (2010). Mapping of Non-Timber Forest Products Using Remote Sensing and GIS, 10.

Tchatat, M., Ousseynou, N., \& Robert, N. (1999). Produits Forestiers Autres que le Bois d'oeuvre (PFAB): place dans l'aménagement durable des forêts denses humides d'Afrique Centrale. Montpellier: CIRAD-Forêt. http://agritrop.cirad.fr/315508/.

Tonga, K., Péguy, L. Z., Louis-Paul-Roger, K. B., \& Dominique, E. (2017). Disponibilité des produits forestiers non ligneux fondamentaux à la périphérie du Parc national de Lobeke. VertigO - la revue électronique en sciences de l'environnement, 17(3), (December). https://doi.org/10.4000/vertigo.18770.

Tsuyuki, S. (Tokyo Univ (Japan)), Lee, J., Phua, M. H., \& Hirata, Y. (2006). Promoting the use of GPS in the forest: Availability of highly sensitive GPS receiver in the forest. Japanese Journal of Forest Planning (Japan).

http://agris.fao.org/agris-search/search.do;jsessionid=43B641792B8FC92D749910262F7A83 01 ?request_locale=zh_CN\&recordID=JP2007003290\&query=\&sourceQuery=\&sortField=\& sortOrder $=\&$ agrovocString $=\& \operatorname{advQuery}=\&$ centerString $=\&$ enableField $=$

Wikipedia. (2018). Meyomessala. Wikipédia.

https://fr.wikipedia.org/w/index.php?title=Meyomessala\&oldid=147325950

\section{Copyright Disclaimer}

Copyright for this article is retained by the author(s), with first publication rights granted to the journal.

This is an open-access article distributed under the terms and conditions of the Creative Commons Attribution license (http://creativecommons.org/licenses/by/4.0/). 